\title{
11 | Social mobilization in Cape Town: a tale of two communities
}

\author{
CHRIS TAPSCOTT
}

Political opportunity theorists (Tilly 1978; McAdam 1982; and Tarrow 1989, among others) have pointed to the fact that the strategies adopted by social movements are contextual and that they are to a considerable extent determined by the prevailing political system and by the opportunities that present themselves for social mobilization. According to Meyer, 'the organisation of the polity and the positioning of various actors within it makes some strategies of influence more attractive and potentially efficacious than others. The wisdom, creativity, and outcomes of activists' choices - their agency - can only be understood and evaluated by looking at the political context and the rules of the game in which those choices are made - that is structure' (Meyer 2004: 129). At the same time, resource mobilization approaches have pointed out that while agency is central to the success of social movements, so too are the material, organizational and intellectual resources at their disposal (McCarthy and Zald 1977). Evidence of this reality is to be found in the burgeoning social mobilization under way in post-apartheid South Africa. As will be seen, however, what differentiates this type of collective action, common in some states in the South, is the fact that it has, for many poor and disadvantaged communities, become a normalized mode of engagement with the state over basic socio-economic rights rather than, as is more often the case in the North, the practice of specific interest groups. What the case studies that follow amply illustrate is the fact that the prevailing political opportunity structures in South Africa are such that resourcedeprived communities have little option but to take to the streets in their struggle to achieve their rights as citizens.

The upsurge in social protest activity in South Africa during the second decade of its new democracy is reflective of the extent to which formal institutional channels for citizen engagement with the state have failed. Indicative of the scale of this trend, some six thousand protests were officially recorded during the 2004/05 financial year and an estimated fifteen protests were being held per day somewhere in South Africa during 2007 (Delaney 2007). The reasons for this failure are extensive and have been 
discussed elsewhere at length and from a variety of different theoretical perspectives (Bond 2000; Terreblanche 2002; Daniel et al. 2005; Ballard et al. 2006; Tapscott 2008; and Piper and Deacon 2008, among others). Most authors concur that while frustration with the slow pace of service delivery and job creation are the proximate stimuli for this protest action, an ensemble of mutually reinforcing factors has given rise to this state of affairs and serves to inhibit the substantive participation of the poor in democratic institutions and processes. Despite the fact that the 1996 constitution and a plethora of policies emanating from that founding document have created an enabling framework for participation, the institutions and processes set in place to engage citizens in this process, the 'invited spaces', have not yielded returns in the form of service delivery (houses, water, electricity, etc.) or job creation. In large part this is due to the fact that the state has set the parameters for engagement in these forums, and has arrogated to itself the right to determine when, how and to whom services are allocated.

While most states presume the right to determine what constitutes the public good, in more consolidated democracies this practice is mediated, to a greater or lesser extent, by the interventions of civil society in the form of opposition parties, the media and other interest groups. In developing states, where civil society is weak, the dominance of the state tends to be aggravated by the political character of the ruling elites. In that respect, a feature of the process of democratic consolidation that has taken place in South Africa since 1994 has been the uneven mutation of the ruling African National Congress (ANC) from a liberation movement to a more formal political power in office. Having swept into office on the tide of popular resistance, the incoming ANC government effectively brought the notion of participation into the political and theoretical mainstream and raised it to a first principle of government policy. It is evident, however, that politically the ANC still perceives itself to be the vanguard of popular struggles and, in so doing, it crowds out attempts by other social movements to represent popular aspirations. In this context, the independent mobilization of citizens on even the most mundane of matters is perceived to be a threat to the status of elected officials and a direct challenge to the party as a whole.

Faced with the reality that the state is generally unresponsive to demands raised through formal institutional channels, disaffected citizens and the organizations that represent them have increasingly sought alternative means to express their grievances. The channels chosen have varied from community to community, according to their social, economic and 
political contexts, and they have differed in their effectiveness in extracting concessions from the state. In essence, nevertheless, these social movements are challenging the hegemony of the state exercised through formally designated sites of participation (including ward committees, public meetings - imbizos - and local elections) and are insisting that their concerns be addressed directly and as a matter of urgency. In eschewing formal channels, furthermore, the options that present themselves for redress are several: to embark on protest action (peaceful, violent or a combination of both) or alternatively to pursue their rights through the courts.

While the resort to violent protest holds the potential to evolve over time into a revolutionary movement with the further potential to overthrow the state, it is evident that this is not the intention of most social movements in South Africa. ${ }^{1}$ Furthermore, while a significant number of service delivery protests have turned violent, there is little evidence to suggest, at the level of individual communities at least, that this form of engagement with the state has yielded any particular gains. Typically, the state has responded with force and has portrayed these struggles as the work of thugs and criminals, thus delegitimizing them in the public eye. This response is typified in a statement by the premier of the Western Cape province following protest action in one of Cape Town's informal settlements.

I am warning that in no way should our sympathy for grievances around housing, services and amenities be interpreted as condoning illegal actions. The police will have no option but to restore order and only then can government enter into discussions around the problems of housing, services and amenities. ... [W]e will not be held hostage to burning barricades and illegal marches. I appeal to those at the forefront of these actions to much rather use the legitimate democratic institutions such as the many Imbizos, the ward committees, the structures for social dialogue and the offices of local councillors and MPs to present their case. If they choose not to do so, then they must face the consequences of a government determined to protect the interests of all its citizens. (Rasool 2005)

For most citizens, therefore, formal political structures, peaceful demonstrations and a recourse to litigation remain the only channels open for the attainment of rights.

The constitution and the legal framework to which it gave rise, however, are based on normative Western ideals of citizenship. Thus the 